\title{
The effects of three silage inoculants on aerobic stability in grass, clover-grass, lucerne and maize silages
}

\author{
Jonas Jatkauskas ${ }^{1 *}$, Vilma Vrotniakiene ${ }^{1}$, Christer Ohlsson ${ }^{2}$ and Bente Lund ${ }^{2}$ \\ ${ }^{1}$ Institute of Animal Science of Lithuanian University of Health Sciences, Baisogala, Lithuania \\ ${ }^{2}$ Chr-Hansen, Hørsholm, Denmark \\ *e-mail: Igipts@gmail.com
}

\begin{abstract}
The objective of the study was to investigate the effects of homofermentative and heterofermentative lactic acid bacteria (LAB) inoculants on fermentation and aerobic stability in a variety of crops and dry matter concentrations. The experiments were conducted with lucerne, ryegrass, ryegrass-timothy, red clover-ryegrass and whole crop maize using three additives in laboratory scale conditions. Each treatment and crop was replicated five times when determining the chemical composition and aerobic stability in the silage. The data were statistically analyzed as a randomized complete block by using the GLM procedure of SAS. Additive application reduced $\mathrm{pH}$ and formation of butyric acid, alcohols and ammonia- $\mathrm{N}$ in all crops compared with the untreated silage $(p<0.05)$. The use of additives increased the content of lactic acid except heterofermentative $L A B$ in maize with $276 \mathrm{~g} \mathrm{~kg}^{-1} \mathrm{DM}$ and increased the content of acetic acid except homofermentative $L A B$ in ryegrass-timothy and maize with $276 \mathrm{~g} \mathrm{~kg}^{-1} \mathrm{DM}$ compared with the untreated silage $(p<0.05)$. It was observed that the aerobic stability of silages was improved significantly $(p<0.05)$ by using homofermentative and heterofermentative LAB inoculants.
\end{abstract}

Key words: ryegrass, lucerne, red clover, maize, lactic acid bacteria, fermentation, aerobic stability

\section{Introduction}

Efficient fermentation of sugar to lactic acid and minimal proteolysis are crucial for silage preservation (Nadeau et al. 2000). It is well documented that the fermentation quality of silages can be improved by lactic acid bacteria based additives (McDonald et al. 1991, Kung et al. 2003, Filya et al. 2007). The mode of action of the additives applied to herbage during silage making can include limiting respiration or proteolysis by plant enzymes, manipulating fermentation, inhibiting the activity of clostridia and aerobic micro-organisms such as yeast and mould (McDonald et al. 1991, Laitila et al. 2002, Rooke and Hatfield 2003, Kung et al. 2003). Driehuis et al. (1999) showed that $L A B$ affected the activity of yeasts in two ways. Firstly during anaerobic conditions, the survival of yeasts is reduced, and secondly, during the aerobic exposure, yeast growth is reduced. Silages treated with inoculants containing various strains of Lactobacillus plantarum had lower yeast, moulds, ethanol, and ammonia-N concentrations than did untreated silages. The silage inoculated with a moderate rate of Lactobacillus buchneri $\left(1 \times 10^{5} \mathrm{cfu}\right.$ $\mathrm{g}^{-1}$ of forage) or the strains of $L$. plantarum enhanced the aerobic stability of the corn silage. The silage treated with L. buchneri $1 \times 10^{6} \mathrm{cfu} \mathrm{g}^{-1}$ of fresh forage underwent a very extensive heterolactic fermentation that resulted in a marked enhancement in aerobic stability (Ranjit and Kung 2000). Inoculating forages at harvest with a heterofermentative LAB species L. buchneri has improved the aerobic stability of the silages (Weinberg et al. 1999), because this organism converts lactic acid to acetic acid under anaerobic conditions (Oude Elferink et al. 2001). Moreover, this inhibits fungi and thus preserves silages susceptible to spoilage upon exposure to air (Filya et al. 2007).

The combination of different cultures of lactic acid bacterial species as a silage inoculant may be more beneficial than using a single species alone due to the differences in growth pattern and positive interaction among bacteria. Recently, L. buchneri has been marketed in combination with homofermentative lactic acid bacteria, which are commonly added into silages to increase lactic acid production, rapidly drop pH, and decrease DM losses (Kung et al. 2003, Jaakkola et al. 2010). The lactic acid bacteria inoculant strains have been selected for rapid growth under wide range of temperatures and dry matter concentrations. These strains are highly competitive and produce largely lactic acid, reducing pH compared to untreated silage (Muck 2012). Recent studies have shown that L. buchneri inhibits yeast and mould growth and increases aerobic stability of silages and these effects are retained when L. buchneri is added in combination with homofermentative lactic acid bacteria (Kleinschmitt et al. 2005). In the study of Jatkauskas and Vrotniakiene (2011) the selected lactic acid bacteria and selected lactic acid bacteria in combination with sodium benzoate or enzime xylanase were efficient in improving red clover-perennial ryegrass silage characteristics in terms of lower $\mathrm{pH}$, ammonia- $\mathrm{N}$ concentrations, reduced DM losses and 
J. Jatkauskas et al. (2013) 22: 137-144

populations of yeasts and mould compared with control silages. Homofermentative LAB in combination with $L$. buchneri or sodium benzoate shifted fermentation towards acetate and had a great effect on the aerobic stability of slightly wilted red clover-ryegrass silage.

The objective of the present study was to investigate the efficacy of the variety of LAB strains on the fermentation characteristics and aerobic stability of lucerne, ryegrass, ryegrass-timothy, red clover-ryegrass and whole crop maize silages.

\section{Material and methods}

Eight trials were conducted in 2009-2011 at the Institute of Animal Science of Lithuanian University of Health Sciences according to the DLG (Deutsche Landwirtschafts-Gesellshaft e.V./ internationally acknowledged German Agricultural Society) Guidelines for the testing of silage additives and to the Guidelines on the assessment of the safety and efficacy of silage additives, on a request from the Commission under Article 7(5) of Regulation (EC) No 1831/2003 (EFSA-Q-2004-088). Adopted on 20 April 2006. In each experiment comparisons were made between untreated silages and inoculated silages.

\section{Test material}

The following LAB combinations were tested: Lactobacillus buchneri CCM 1819 (TA); Lactobacillus buchneri CCM 1819, Enterococcus faecium NCIMB 11181 and Lactobacillus plantarum DSM 16568 (TB); and Enterococcus faecium NCIMB 11181, Lactobacillus plantarum DSM 16568 and Lactococcus lactis DSM 11037 supplemented with sodium benzoate at $400 \mathrm{~g}^{-1}$ ton forage (TC). Lactic acid bacteria strains rather than formulations were registered as silage additives in the EU. Therefore, trade names are not provided in Table 1.

Table1. Blend of bacterial strains or/and other components that were used as test material

\begin{tabular}{|c|c|c|c|c|}
\hline Inoculant & Bacterial srains or/and other components & $\begin{array}{l}\text { Bacterial } \\
\text { proportion, \% }\end{array}$ & $\begin{array}{l}\text { Actual count in } \\
\text { product, cfu g }{ }^{-1}\end{array}$ & $\begin{array}{l}\text { Application rate, } \mathrm{cfu} \mathrm{g}^{-1} \\
\text { fresh forage }\end{array}$ \\
\hline TA & Lactobacillus buchneri CCM 1819 & 100 & $2.4 \mathrm{E}+11$ & $\begin{array}{l}150 \text { 000-L, R, RC:R } \\
(70: 30), R: T(70: 30), M 1 \\
M 2, M 3\end{array}$ \\
\hline TB & $\begin{array}{l}\text { Lactobacillus buchneri CCM 1819, } \\
\text { Enterococcus faecium NCIMB 11181, } \\
\text { Lactobacillus plantarum DSM } 16568\end{array}$ & 50: 30: 20 & $2.8 E+11$ & 150 000-RC:R (50:50), M3 \\
\hline $\mathrm{TC}$ & $\begin{array}{l}\text { Enterococcus faecium NCIMB } 11181 \text {, } \\
\text { Lactobacillus plantarum DSM } 16568 \text {, } \\
\text { Lactococcus lactis DSM } 11037+\mathrm{NaB} \text { at } \\
400 \mathrm{~g}^{-1} \text { ton forage }\end{array}$ & 40: $30: 30$ & $2.29 E+11$ & $\begin{array}{l}150 \text { 000-R:T (70:30), RC:R } \\
\text { (50:50), M3 }\end{array}$ \\
\hline
\end{tabular}

$\mathrm{NaB}=$ sodium benzoate, $\mathrm{cfu}=$ colony-forming units, $\mathrm{L}=$ lucerne, $\mathrm{R}=$ ryegrass, $\mathrm{RC}: \mathrm{R}=$ red clover:ryegrass, $\mathrm{R}: \mathrm{T}=$ ryegrass:timothy, $\mathrm{M} 1=$ whole crop maize (DM $\left.328 \mathrm{~g} \mathrm{~kg}^{-1}\right), \mathrm{M} 2$ = whole crop maize (DM $\left.295 \mathrm{~g} \mathrm{~kg}^{-1}\right), \mathrm{M} 3$ = whole crop maize (DM $276 \mathrm{~g} \mathrm{~kg}^{-1}$ )

The inoculants were supplied by Chr. Hansen A/S (Hørsholm, Denmark) as freeze-dried powders, sealed aluminium pouches clearly labelled. The test materials were stored at temperatures below $5^{\circ} \mathrm{C}$ until used. Opened pouches were discarded after use.

\section{Crop material and micro-silo preparation}

Lucerne (Medicago sativa L.) two-years-old, second cut, at early bloom stage of maturity (L), perennial ryegrass (Lolium perenne L.) 1-year-old, second cut, at midbloom stage of maturity (R), a mixture of red clover (Trifolium pretense L.) and perennial ryegrass (Lolium perenne L.) with two-years old, second cut, at early bloom stage of maturity of red clover (RC:R, 70:30 on a fresh weight basis), a mixture of perennial ryegrass (Lolium perenne L.) and timothy (Phleum pratense L.) 1-year-old, second cut, when the timothy was 50-75\% headed (R:T, 70:30 on a fresh weight basis), a mixture of red clover (Trifolium pretense L.) and perennial ryegrass (Lolium perenne L.) with two-years-old, second cut, at the early bloom stage of maturity of red clover (RC:R, 50:50 on a fresh weight basis) and whole crop maize (Zea mays L.) at the dough stage of maturity (M1, $328 \mathrm{~g} \mathrm{~kg}^{-1} \mathrm{DM}$ ) and milk dough stage of maturity (M2, $295 \mathrm{~g} \mathrm{~kg}^{-1} \mathrm{DM}$ and $\left.\mathrm{M} 3,276 \mathrm{~g} \mathrm{~kg}^{-1} \mathrm{DM}\right)$ were used in the present study. The herbages were cut 
by a mower conditioner (Kverneland Taarup) and wilted for 8-12 hours. Wilted crops were chopped by a forage harvester under farm conditions to 2-3 cm length. Whole crop maize was harvested and chopped with a maize harvester (Class Jaguar 840) to a length of $<2>\mathrm{cm}$. Chopped forage was transported in a polyethylene bag to the laboratory. Laboratory experiments started within $2 \mathrm{~h}$ from crop preparation. Three silage inoculants were used in the experiments.

The application rates of the inoculants were in accordance with the level of LAB in the inoculants as determined by manufacturer and in accordance with Table 1 . The test materials were suspended in chlorine free $\mathrm{H}_{2} \mathrm{O}$ immediatly prior to application targeting in a concentration of cells of $1.5 \times 10^{8} \mathrm{cfu} \mathrm{ml}^{-1}$ suspension. Additionally, $400 \mathrm{~g}$ sodium benzoate for TC was diluted in 1 litre of distilled water. $1.00 \mathrm{ml}$ of each suspension was used per $1 \mathrm{~kg}$ forage (added $3 \mathrm{ml}$ of chlorine-free water for uniform spraying). The same volume ( $4 \mathrm{ml} \mathrm{g}^{-1}$ of fresh forage) of chlorinefree water was used instead of the suspension in the control treatment (for spontaneous fermentation). Subsequently, the additives and water were sprayed into the fresh forage using a spray bottle and the forage was thoroughly mixed. The number of viable bacteria in each suspension was counted on DeMan-Rogosa-Sharpe (MRS) agar after incubation anaerobically at $37^{\circ} \mathrm{C}$ for 48 h. (ISO 15214, Leuschner et al. 2003).

The 3-litre mini-silos (glass jars) were filled with chopped lucerne (L), ryegrass (R), red clover:ryegrass (RC:R, 70:30), ryegrass-timothy ( $R: T, 70: 30)$, red clover-ryegrass (RC:R, 50:50), and whole crop maize (M1, $M 2$ and $M 3)$. Each treatment and crop was replicated five times. The density of forage in the silage was in compliance with DLG recommendations, $1 \mathrm{~kg}$ DM per 5 litre volume. The silos were closed immediately with caps, with a potential to vent gas, $30 \mathrm{~min}$ after being filled. Ensiling lasted for 90 days at a constant temperature of $20^{\circ} \mathrm{C}$. At the end of the ensiling period, the silages were subjected to chemical analysis and to aerobic stability test.

\section{Sampling and chemical analysis}

Before ensiling five representative samples (> $500 \mathrm{~g}$ each) of each fresh chopped forage were collected for the subsequent chemical analysis. At the sampling time of silages on day 90 of the ensiling period, five micro-silos per treatment were weighed for determination of DM loss and subsequently opened and sampled to analyze the DM content, $\mathrm{pH}$, fermentation products and ammonia- $\mathrm{N}$. The DM content of forage and silage was determined by oven-drying at $105^{\circ} \mathrm{C}$ for $24 \mathrm{~h}$. For the analysis of the chemical composition of herbage, the samples were ovendried $\left(1 \mathrm{~h}\right.$ at $102{ }^{\circ} \mathrm{C}$ and $48 \mathrm{~h}$ at $\left.50{ }^{\circ} \mathrm{C}\right)$ and then ground to pass a $1-\mathrm{mm}$ sieve. Silage DM content was corrected for volatile alcohols and fatty acids during oven drying as described by Weissbach (2009). The total nitrogen was determined by Kjeldahl-AOAC 984.13 (AOAC 1990). Crude protein (CP) content was calculated by multiplying the total nitrogen content by a factor of 6.25. The NDF and ADF concentrations were determined according to Van Soest et al. (1991) by using an Ankom ${ }^{200}$ fiber analyzer ("Ankom Technology", USA). Water soluble carbohydrates (WSC) were determined using the anthrone reaction assay from the herbage or silage extracts obtained from steeping fresh herbage or silage in water (Faithfull 2002). Ash concentration was determined by ashing the samples in a furnace at $600{ }^{\circ} \mathrm{C}$ for $15 \mathrm{~h}$. Buffering capacity of the forage was determined according to Playne and McDonald (1966), expressed as $\mathrm{mEq}$ of alkali required to change the $\mathrm{pH}$ from 4 to 6 per $1 \mathrm{~kg}$ of DM. Lactic acid, volatile fatty acid, alcohol, and ammonia $\mathrm{N}$ concentrations and $\mathrm{pH}$ were determined in silage extracts, prepared by adding 270 $\mathrm{g}$ of demineralized, deionized water to $30 \mathrm{~g}$ of silage and homogenizing for $5 \mathrm{~min}$ in a laboratory blender. Lactic acid, volatile fatty acids and alcohol concentrations were determined by gas-liquid chromatography. Gas-liquid chromatograph "GC-2010 Shimadzu" with capillary column (Stabilwax-DA 30m, 0.53mm, ID, 0.5 $\mu \mathrm{m}$ ) was used according to Gas Chromatography and Biochemistry Analyzer official methods. Ammonia-N concentration was determined by direct distillation using the "Kjeltec Auto System 1030" (AOAC 1990 941.04). The pH of silage was measured by using "Thermo Orion Posi-pHlo SympHony" electrode and "Thermo Orion 410" meter. Dry matter losses were estimated by measuring differences in silo weights after ensiling (on day 0 after ensiling) and at the end of the ensiling period (on day 90 after ensiling).

\section{Aerobic stability measurement}

After opening the micro-silos, all silages were subjected to a 19-day aerobic stability test. A $1000 \pm 10$ g sample from each silo (five silos from each treatment) was loosely placed into a polystyrene box according to recommendations from DLG and allowed to aerobically deteriorate at constant room temperature $\left(\sim 20^{\circ} \mathrm{C}\right)$. The top and bottom of the boxes contained a 2-cm-diameter hole to allow air to enter and $\mathrm{CO}_{2}$ to leave. A transducer was placed in the centre of the silage mass through a hole in the cover of the box, which exposed the silage to air. These silages were not disturbed during the period of recording the temperatures. Ambient temperature and the temperature of each silage was recorded every $6 \mathrm{~h}$ by a data logger. Ambient room temperature was measured 
by using an empty control box. Aerobic stability of silages was examined by calculating the differences between silage temperature and ambient room temperature adjusted for base ambient temperature. Aerobic stability was defined as the number of hours the silage remained stable before rising more than $3^{\circ} \mathrm{C}$ above the ambient temperature (Moran et al. 1996).

\section{Statistical analyses}

Silage composition data and aerobic stability data (hours for a $3{ }^{\circ} \mathrm{C}$ increase in temperature) for each herbage type separately were analyzed using Proc GLM of SAS (Statistical Analysis System SAS ${ }^{\circ}$, version 8.02, 2000) and LSD tests were used to indicate significant differences between untreated and additive treatment. Significance was declared at $p<0.05$.

\section{Results \\ Characteristics of the forages}

The data on the composition of the herbages at the time of silo filling are presented in Table 2 . The lucerne cultivar was wilted up to $328 \mathrm{~g} \mathrm{~kg}^{-1}$ and had a very low WSC concentration and high crude protein concentration and buffering capacity. Consequently, $\mathrm{L}$ was characterised as difficult to ensile. The ryegrass was wilted up to $308 \mathrm{~g} \mathrm{~kg}^{-1}$ DM concentration. The concentrations of WSC (85 $\left.\mathrm{g} \mathrm{kg}^{-1} \mathrm{DM}\right)$ and crude protein (153 $\left.\mathrm{g} \mathrm{kg}^{-1} \mathrm{DM}\right)$ were medium. The buffering capacity was typical for R herbage. The red clover: ryegrass sward (70:30) was wilted up to $317 \mathrm{~g}$ $\mathrm{kg}^{-1}$ of DM concentration. The concentration of WSC was medium (92 $\mathrm{g} \mathrm{kg}^{-1} \mathrm{DM}$ ) and crude protein concentration was high (199 $\left.\mathrm{g} \mathrm{kg}^{-1} \mathrm{DM}\right)$. A mixture of ryegrass:timothy (70:30) was wilted to $265 \mathrm{~g} \mathrm{~kg}^{-1} \mathrm{DM}_{\text {concentration. The }}$ concentrations of WSC (102 $\left.\mathrm{g} \mathrm{kg}^{-1} \mathrm{DM}\right)$ and crude protein (172 $\left.\mathrm{g} \mathrm{kg}^{-1} \mathrm{DM}\right)$ were medium. The buffering capacity was typical for R:T herbage.

Table 2. Chemical composition ( $\mathrm{g} \mathrm{kg}^{-1} \mathrm{DM}$ unless otherwise stated) and microbial parameters of herbage prior to ensiling. Means of five samples.

\begin{tabular}{|c|c|c|c|c|c|c|c|c|}
\hline Variable & L & $\mathrm{R}$ & $\begin{array}{c}\text { RC:R } \\
(70: 30)\end{array}$ & R:T (70:30) & $\begin{array}{c}\mathrm{RC}: \mathrm{R} \\
(50: 50)\end{array}$ & M1 & M2 & M3 \\
\hline Dry matter $\left(\mathrm{g} \mathrm{kg}^{-1}\right)$ & 328 & 308 & 317 & 265 & 266 & 276 & 295 & 328 \\
\hline Crude protein & 229 & 153 & 199 & 172 & 174 & 89 & 90 & 89 \\
\hline Neutral detergent fibre & 414 & 484 & 363 & 493 & 361 & 466 & 443 & 447 \\
\hline WSC & 49 & 85 & 92 & 102 & 89 & 99 & 95 & 110 \\
\hline Crude ash & 84 & 79 & 65 & 87 & 99 & 50 & 52 & 47 \\
\hline $\mathrm{BC}, \mathrm{mE} \mathrm{kg}{ }^{-1} \mathrm{DM}$ & 564 & 242 & 328 & 355 & 365 & 217 & 152 & 228 \\
\hline $\mathrm{pH}$ & 6.4 & 6.5 & 5.9 & 6.3 & 6.6 & 5.7 & 5.6 & 5.7 \\
\hline Nitrate, $\mathrm{mg} \mathrm{kg}^{-1} \mathrm{DM}$ & 840 & 146 & 187 & 153 & 243 & 841 & 436 & 746 \\
\hline Clostridia, log cfu g-1 & $<0.1$ & $<0.1$ & $<0.1$ & $<1.0$ & $<0.1$ & $<1.0$ & $<0.1$ & $<0.1$ \\
\hline Yeasts, log cfu g ${ }^{-1}$ & 3.2 & 3.5 & 3.3 & 3.8 & 5.1 & 4.3 & 4.5 & 5.6 \\
\hline Moulds, log cfu g ${ }^{-1}$ & 3.7 & 4.4 & 4.1 & 4.9 & 5.5 & 4.6 & 4.8 & 6.0 \\
\hline
\end{tabular}

WSC = Water soluble carbohydrates, $B C=$ Buffering capacity, $L=$ lucerne, $R=$ ryegrass, RC:R = red clover:ryegrass, $\mathrm{R}: \mathrm{T}=$ ryegrass:timothy, $\mathrm{M} 1$

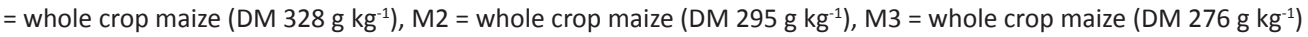

The red clover:ryegrass (RC:R) sward (50:50) was wilted up to $265 \mathrm{~g} \mathrm{~kg}^{-1} \mathrm{DM}$ concentration. The concentration of WSC was medium ( $\left.89 \mathrm{~g} \mathrm{~kg}^{-1} \mathrm{DM}\right)$ and that of crude protein was high (172 $\left.\mathrm{g} \mathrm{kg}^{-1} \mathrm{DM}\right)$. Whole crop maize (M1, M2 and M3) contained medium DM concentration (276-328 $\mathrm{g} \mathrm{kg}^{-1}$ ), WSC concentration was medium (95-110 g kg-1 $\mathrm{DM}$ ) and crude protein low (89-90 $\left.\mathrm{g} \mathrm{kg}^{-1} \mathrm{DM}\right)$. The buffering capacity was typical of whole crop maize herbage. Consequently, R, RC:R, R:T, M1, M2 and M3 forages were characterized as moderately difficult to easy to ensile.

\section{Silage fermentation and aerobic stability}

Chemical composition, microbial parameters and aerobic stability of the untreated and treated with TA, TB, and TC additives grass and clover-grass silages are presented in Table 3.

Addition of inoculants TA, TB and TC lowered $(p<0.05)$ the $\mathrm{pH}$, increased $(p<0.05)$ lactic acid and acetic acid formation (except R:T (70:30) inoculated with TC) and decreased $(p<0.05)$ dry matter losses in R, RC:R (70:30), R:T $(70: 30)$ and $R C: R(50: 50)$ silages compared to the untreated control. Lactic acid was the predominant fermentation 
product detected in R:T (70:30) and RC:R (50:50) silages inoculated with TC. Marked increases $(p<0.05)$ in lactic acid contents in TC- inoculated R:T (70:30) and RC:R (50:50) resulted in the highest lactic to acetic acid ratios in comparison with the other treatments. Ammonia- $\mathrm{N}$, butyric acid and ethanol concentrations were decreased ( $p$ $<0.05)$ in all inoculated silages compared with the corresponding untreated control.

Aerobic stability expressed as the number of hours the silage remained stable before temperature rising more than $3^{\circ} \mathrm{C}$ above the ambient temperature was significantly increased $(p<0.05)$ in the $\mathrm{R}, \mathrm{RC}: \mathrm{R}(70: 30), \mathrm{R}: \mathrm{T}(70: 30)$ and RC:R (50:50) silages inoculated with TA, TB and TC as compared with corresponding UT silages.

The number of yeasts and moulds were significantly lower $(p<0.05)$ in TA treated R and R:T $(70: 30)$ silages, and numerically lower in TC inoculated R:T (70:30) silages as compared with UT silages.

Table 3. Chemical composition ( $\mathrm{g} \mathrm{kg}^{-1} \mathrm{DM}$ unless otherwise stated) and aerobic stability of the grass and clover-grass silages

\begin{tabular}{|c|c|c|c|c|c|c|c|c|c|c|c|c|c|c|}
\hline \multirow[t]{2}{*}{ Item } & \multicolumn{3}{|c|}{$\mathrm{R}$} & \multicolumn{3}{|c|}{ RC:R (70:30) } & \multicolumn{4}{|c|}{ R:T (70:30) } & \multicolumn{4}{|c|}{$\mathrm{RC}: \mathrm{R}(50: 50)$} \\
\hline & UT & TA & SEM & UT & TA & SEM & UT & TA & TC & SEM & UT & TB & $\mathrm{TC}$ & SEM \\
\hline Dry matter, $\mathrm{g} \mathrm{kg}^{-1}$ & 292 & $301 *$ & 1.8 & 294 & 299* & 1.4 & 250 & 252 & 253 & 0.9 & 239 & $250 *$ & $252 *$ & 1.8 \\
\hline Dry matter loss, $\%$ & 7.0 & $4.1^{*}$ & 0.53 & 10.2 & $6.7^{*}$ & 0.57 & 6.3 & 5.8 & $4.9 *$ & 0.21 & 12.3 & $6.7^{*}$ & $5.7^{*}$ & 0.83 \\
\hline $\mathrm{pH}$ & 5.1 & $4.3^{*}$ & 0.13 & 4.7 & $4.3^{*}$ & 0.07 & 4.6 & $4.2^{*}$ & $3.9 *$ & 0.07 & 5.6 & $4.7^{*}$ & $4.4^{*}$ & 0.134 \\
\hline $\begin{array}{l}\mathrm{NH}_{3} \mathrm{~N}, \\
\mathrm{~g} \mathrm{~kg}^{-1} \mathrm{~N}\end{array}$ & 59 & $45^{*}$ & 2.3 & 57 & $40 *$ & 3.7 & 60 & $51^{*}$ & $44^{*}$ & 2.0 & 92 & $52 *$ & $52^{*}$ & 5.7 \\
\hline Lactic acid & 23 & $40 *$ & 3.3 & 27 & $32 *$ & 2.1 & 31 & 34 & $72 *$ & 5.1 & 14 & $38 *$ & $57 *$ & 5.2 \\
\hline Acetic acid & 22 & $35^{*}$ & 2.3 & 29 & $38 *$ & 2.1 & 28 & $46^{*}$ & $19 *$ & 3.1 & 18 & $32 *$ & $33^{*}$ & 2.3 \\
\hline Butyric acid & 4.7 & $0.4^{*}$ & 0.87 & 6.5 & $0.3^{*}$ & 1.34 & 2.5 & 1.9 & $0.7^{*}$ & 0.26 & 37.5 & $1.9 *$ & $0.3^{*}$ & 4.63 \\
\hline Ethanol & 9.0 & $7.0^{*}$ & 0.48 & 11.0 & $7.0^{*}$ & 0.85 & 7.0 & $6.0^{*}$ & $5.0^{*}$ & 0.26 & 14.0 & $6.0^{*}$ & $4.0^{*}$ & 1.32 \\
\hline AS- hours & 62 & $257 *$ & 19.6 & 96 & $168 *$ & 5.9 & 104 & $312^{*}$ & $182^{*}$ & 15.7 & 198 & $450 *$ & $370 *$ & 14.8 \\
\hline Yeasts, log cfu g-1 & 2.9 & $1.0 *$ & 0.33 & - & - & - & 3.2 & $1.3^{*}$ & 1.5 & 0.26 & - & - & - & - \\
\hline Moulds,log cfu g ${ }^{-1}$ & 4.1 & $1.3^{*}$ & 0.50 & - & - & - & 3.0 & $1.3^{*}$ & 1.4 & 0.22 & - & - & - & - \\
\hline
\end{tabular}

$\mathrm{R}=$ ryegrass, $\mathrm{RC}: \mathrm{R}=$ red clover:ryegrass, $\mathrm{R}: \mathrm{T}=$ ryegrass:timothy, $\mathrm{UT}=$ untreated, $\mathrm{TA}=$ Lactobacillus buchneri $\mathrm{CCM} 1819, \mathrm{TC}=$ Enterococcus faecium NCIMB 11181, Lactobacillus plantarum DSM 16568 and Lactococcus lactis DSM 11037 supplemented with sodium benzoate at 400 $\mathrm{g}^{-1}$ ton forage, $\mathrm{SEM}=$ standard error of mean, $\mathrm{TB}=$ Lactobacillus buchneri CCM 1819, Enterococcus faecium NCIMB 11181 and Lactobacillus plantarum DSM $16568,{ }^{*}=$ denotes significant compared to untreated control at level 0.05 .

Chemical composition, microbial parameters and aerobic stability of the untreated and treated with TA, TB, and TC additives lucerne and maize silages are presented in Table 4.

Table 4. Chemical composition ( $\mathrm{g} \mathrm{kg}^{-1} \mathrm{DM}$ unless otherwise stated) and aerobic stability of the lucerne and maize silages

\begin{tabular}{|c|c|c|c|c|c|c|c|c|c|c|c|c|c|c|}
\hline \multirow[t]{2}{*}{ Item } & \multicolumn{3}{|c|}{$\mathrm{L}$} & \multicolumn{3}{|c|}{ M 1} & \multicolumn{3}{|c|}{ M 2} & \multicolumn{5}{|c|}{ M 3} \\
\hline & UT & TA & SEM & UT & TA & SEM & UT & TA & SEM & UT & TA & TB & TC & SEM \\
\hline Dry matter, $\mathrm{g} \mathrm{kg}^{-1}$ & 313 & $319 *$ & 3.3 & 312 & 314 & 0.8 & 282 & $287^{*}$ & 1.4 & 264 & 268 & 269 & $269 *$ & 1.3 \\
\hline Dry matter loss, \% & 6.8 & $4.6^{*}$ & 0.26 & 7.4 & $5.8^{*}$ & 0.37 & 5.9 & $3.8^{*}$ & 0.43 & 5.5 & $3.8^{*}$ & $3.7^{*}$ & $3.6^{*}$ & 0.22 \\
\hline $\mathrm{pH}$ & 5.4 & $5.0^{*}$ & 0.04 & 4.0 & $3.7^{*}$ & 0.05 & 3.9 & $3.7^{*}$ & 0.04 & 3.7 & $3.6^{*}$ & $3.6^{*}$ & $3.6^{*}$ & 0.11 \\
\hline $\mathrm{NH}_{3} \mathrm{~N}, \mathrm{~g} \mathrm{~kg}^{-1} \mathrm{~N}$ & 102 & $79 *$ & 2.9 & 61 & $52 *$ & 2.3 & 80 & $57^{*}$ & 4.7 & 58 & $48^{*}$ & $46^{*}$ & $47^{*}$ & 1.9 \\
\hline Lactic acid & 17 & $39 *$ & 2.5 & 28 & $34^{*}$ & 1.5 & 40 & $50^{*}$ & 2.32 & 56 & $50 *$ & 56 & $74 *$ & 2.2 \\
\hline Acetic acid & 34 & $49^{*}$ & 2.3 & 26 & $36^{*}$ & 1.8 & 19 & 18 & 0.4 & 26 & $38^{*}$ & $33^{*}$ & $22^{*}$ & 1.5 \\
\hline Butyric acid & 14 & $1.0^{*}$ & 1.68 & 1.9 & $0.2^{*}$ & 0.37 & 0.5 & $0.2^{*}$ & 0.09 & 0.5 & $0.1^{*}$ & $0.1^{*}$ & $0.0^{*}$ & 0.04 \\
\hline Ethanol & 12 & $7.0 *$ & 0.77 & 27.1 & $18.4^{*}$ & 1.68 & 11.2 & $8.1^{*}$ & 0.51 & 10.3 & $7.5^{*}$ & $6.0^{*}$ & $7.0^{*}$ & 0.36 \\
\hline AS, hours & - & - & & 66 & $142^{*}$ & 5.4 & 46 & $76^{*}$ & 3.8 & 61 & $151^{*}$ & $143^{*}$ & $145^{*}$ & 11.7 \\
\hline Yeasts, log cfu g ${ }^{-1}$ & - & - & & 3.4 & $2.9^{*}$ & 0.13 & 2.2 & $1.4^{*}$ & 0.12 & 1.9 & 1.1 & 1.2 & 1.3 & 0.13 \\
\hline Mould, log cfu g-1 & - & - & & 4.1 & $3.5^{*}$ & 0.15 & 1.8 & $1.1^{*}$ & 0.15 & 2.0 & 1.0 & 1.1 & 1.3 & 0.12 \\
\hline
\end{tabular}

$\mathrm{L}=$ Lucerne, $\mathrm{M} 1$ = whole crop maize $\left(\mathrm{DM} 328 \mathrm{~g} \mathrm{~kg}^{-1}\right), \mathrm{M} 2=$ whole crop maize $\left(\mathrm{DM} 295 \mathrm{~g} \mathrm{~kg}^{-1}\right), \mathrm{M} 3$ = whole crop maize $\left(\mathrm{DM} 276 \mathrm{~g} \mathrm{~kg}{ }^{-1}\right), \mathrm{UT}=$ untreated, TA = Lactobacillus buchneri CCM 1819, SEM = standard error of mean, TC = Enterococcus faecium NCIMB 11181, Lactobacillus plantarum DSM 16568 and Lactococcus lactis DSM 11037 supplemented with sodium benzoate at $400 \mathrm{~g}^{-1}$ ton forage, TB = Lactobacillus buchneri CCM 1819, Enterococcus faecium NCIMB 11181 and Lactobacillus plantarum DSM 16568, * = denotes significant compared to untreated control at level 0.05 .

Addition of inoculants TA, TB and TC lowered $(p<0.05)$ the $\mathrm{pH}$, increased $(p<0.05)$ lactic acid concentration (except M3 treated with TB), increased $(p<0.05)$ acetic acid formation (except M2 treated with TA) and decreased $(p<0.05)$ dry matter losses in L, M1,M2 and M3 silages compared with the corresponding untreated control (UT). 
J. Jatkauskas et al. (2013) 22: 137-144

Lactic acid was the predominant fermentation product detected in M3 TC inoculated silages which resulted in the highest lactic to acetic acid ratios relative to other treatments. Ammonia- $\mathrm{N}$, butyric acid and ethanol concentrations were decreased $(p<0.05)$ in all inoculated silages compared with the corresponding untreated control (UT).

Aerobic stability expressed as the number of hours the silage remained stable before temperature rising more than $3{ }^{\circ} \mathrm{C}$ above the ambient temperature was significantly increased $(p<0.05)$ in the M1 and M2 TA treated silages and in M3 TA, TB and TC inoculated silages as compared with corresponding UT silages. The numbers of yeasts and moulds were significantly lower $(p<0.05)$ in the M1 and M2 TA inoculated silages, and numerically lower in M3 silages inoculated with TA, TB and TC.

\section{Discussion}

The LAB strains heterolactic Lactobacillus buchneri CCM 1819, heterolactic Lactobacillus buchneri CCM 1819 in combination with homolactic Enterococcus faecium NCIMB 11181 and Lactobacillus plantarum DSM 16568, and homolactic Enterococcus faecium NCIMB 11181, Lactobacillus plantarum DSM 16568 and Lactococcus lactis DSM 11037 in combination with sodium benzoate as silage inoculants were investigated in difficult to ensile crop lucerne, in moderately easy to ensile crops ryegrass, red clover:ryegrass and ryegrass:timothy, and in easy to ensile crop whole crop maize.

The crop material used in this experiment had a low dry matter concentration and in this respect the raw material was demanding for the inoculants. It was expected that $L A B$ will increase the fermentation rate, causing the $\mathrm{pH}$ to decline lower. By using heterolactic $L A B$ strain or heterolactic LAB strain in combination with homolactic $L A B$ strains products of fermentation are increased, resulting in more lactic acid and more acetic acid. It was observed that using homolactic LAB strains in combination with sodium benzoate increased lactate concentration, but decreased (except RC:R 50:50) acetate concentration. In the studies in which L.buchneri was used as an inoculant for silage fermentation, an anaerobic degradation of moderate amounts of lactic acid to acetic acid under anaerobic conditions was observed (Driehuis et al. 1999). Oude Elferink et al. (2001) concluded that the lactic acid conversion rate can be influenced by the temperature of the silage, the number of $L$. buchneri or relatives present, and the strain used.

The importance of a rapid drop in $\mathrm{pH}$ and increasing of lactic acid for silage quality is apparent when the UT and LAB-inoculated silages are compared. Inoculation reduced ammonia-N production compared with corresponding untreated control. Multiplication of clostridia and enterobacteria, which are responsible for protein degradation resulting in the formation of ammonia, stops at pH 4.5 (Pahlow et al. 2003). The positive effects of LAB inoculants on nitrogen fractions can be explained either by domination of the fermentation resulting in the rapid achievement of a low pH or via the low proteolytic activity of the strains (Winters et al. 2000). In the present study the use of inoculants reduced fermentation losses by $2.7 \%$ units (variation from 0.5 to $6.6 \%$ units) compared to the corresponding UT silages. Filya et al. (2007) and Wyss and Rubenshuh (2012) concluded that main effect of silage inoculants was the increased production of lactic acid which in connection with significant reduction of $\mathrm{pH}$ value, improved the silage quality and minimised dry matter losses.

All the additives improved the fermentation quality compared with the corresponding UT silages, especially in terms of the ammonia- $\mathrm{N}$, which was $9-40 \mathrm{~g} \mathrm{~kg}^{-1} \mathrm{~N}$ lower in the inoculated than in the corresponding UT silages. Regarding the used LAB inoculants, the results agree with the laboratory scale experiments (Saarisalo et al. 2006a) in which inoculation resulted in a drop in $\mathrm{pH}$, increased lactic acid production and restricted ammonia- $\mathrm{N}$ production.

The results of the present study indicate clearly that heterolactic $L$. buchneri CCM 1819 or heterolactic L. buchneri CCM 1819 in combination with homolactic Enterococcus faecium NCIMB 11181 and Lactobacillus plantarum DSM 16568 improved the aerobic stability of silages. The explanation for the aerobic stability increasing effect of L. buchneri can be that the activity of yeasts is impaired. Yeasts are generally the initiators of aerobic deterioration, consuming sugars and fermentation acids and raising silage temperature (Pahlow et al. 2003). Finally, moulds complete the deterioration of the silages (Dolci et al. 2011). In the present experiment another indicator showing that yeast activity was suppressed was lower ethanol concentration of the inoculated silages when compared with the corresponding UT silages. Acetic acid is a fungicidal agent and can inhibit the growth of yeasts and moulds, in response to the increasing aerobic stability of silages (Danner et al. 2003, Schmidt et al. 2009). Kleinschmitt and Kung (2006) indicated that the improved aerobic stability has been observed in different types of forages when acetic and propionic acid production in silage fermentation increased with $L$. buchneri inoculation. However, König 
et al. (2012) suggest that the use of a pure L. buchneri additive on forages with a low dry matter content is not appropriate due to the excessive fermentation and furthermore, high acetic acid concentration is not necessary for aerobic stability improvement. The improvement of aerobic stability was observed in a RC:R (50:50), R:T (70:30) and M3 silages by using homolactic LAB strains in combination with sodium benzoate. Sodium benzoate inhibits spore-forming bacteria, yeasts and moulds (Woolford 1975). A beneficial effect of sodium benzoate on silage quality was demonstrated by Kleinschmit et al. (2005). Jaakkola et al. (2010) observed that the combination of $L$. plantarum with sodium benzoate was more efficient than the combination of L. plantarum and L. buchneri. In the experiment of Saarisalo et al. (2006b) the aerobic stability of silages was increased by inoculation with $L$. plantarum and was distinctly increased by treatment with L. plantarum in combination with sodium benzoate compared with untreated silage. Some inoculant lactic acid bacteria strains produce anti-microbial compounds that inhibit mould growth or undesirable bacterial species like Salmonella sp., Listeria sp. and Escherichia coli (Gollop et al. 2005). The mixture of Lactobacillus plantarum and Enterococcus faecium used inhibited the development of yeast and mould populations in barley silage, both during ensiling and upon aerobic exposure and increased aerobic stability (McAlister et al. 1995).

\section{Conclusions}

In conclusion, the novel LAB strains or LAB strains in combination with sodium benzoate were effective in improving fermentation quality, and especially in reducing ammonia- $\mathrm{N}$ formation, dry matter losses and number of yeasts and moulds in legume, grass, grass:legume or whole crop maize silages compared with the untreated control.

The aerobic stability was significantly improved compared to control in silages inoculated with L. buchneri, L. buchneri in combination with homolactic $L A B$, and homolactic $L A B$ in combination with sodium benzoate.

\section{References}

AOAC. 1990. Official Methods of Analysis Association of Official Analytical Chemists. 15th ed. Washington: Association of Official Analytical Chemists: 74-76.

Danner, H., Holzer, M., Mayrhuber, E. \& Braun, R. 2003. Acetic acid increases Stability of silages under aerobic conditions. Journal of Applied and Environmental Microbiology 69: 562-567.

Dolci P., Tabacco, E., Cocolin L. \& Borreani, G. 2011. Microbial dynamics during aerobic exposure of corn silage stored under oxygen barrier or polyethylene films. Journal of Applied and Environmental Microbiology 77: 7499-7507.

Driehuis, F., Oude Elferink, S. \& Spoelstra, S. 1999. Anaerobic lactic acid degradation during ensilage of whole crop maize inoculated with Lactobacillus buchneri inhibits yeast growth and improves aerobic stability. Journal of applied Microbiology 87: 585-594.

Faithfull, N. 2002. Methods in Agricultural Chemical Analyse. A Practical Handbook. CABI Publishing. Institute of Rural Studies, University of Wales, Aberrystwyh, UK. 206 p.

Filya, I., Muck, R. \& Contreras-Govea, F. 2007. Inoculant effects on alfalfa silage: fermentation products and nutritive value. Journal of Dairy Science 90: 5108-5114.

Gollop, N., Zakin, V. \& Weinberg, Z. 2005. Antibacerial activity of lactic acid bacteria included in inoculants for silage and in silages treated with these inoculants. Journal of Applied Microbiology 98: 662-666.

Jaakkola, S., Saarisalo, E. \& Heikkilä, T. 2010. Aerobic stability and fermentation quality of round bale silage treated with inoculants or propionic acid. Grassland Science in Europe 15: 503-505.

Jatkauskas, J. \&Vrotniakiene, V. 2011. The effects of silage inoculants on the fermentation and aerobic stability of legume-grass silage. Žemdirbystè-Agriculture 98: 367-374.

Kleinschmitt, D., Schmidt, R. \& Kung, L. 2005. The effects of variuos antifungal additives on the fermentation and aerobic stability of corn silage. Journal of Dairy Science 88: 2130-2139.

Kleinschmitt, D. \& Kung, L. 2006. A meta-analysis of the effects of Lactobacillus buchneri on the fermentation and aerobic stability of corn and grass and small-grain silages. Journal of Dairy Science 89: 4005-4013.

König, W., Puhakka, L. \& Jaakkola, S. 2012. The effects of lactic acid bacteria-based additives and wilting on grass silagefermentation characteristics. In: Kuoppala, K. et al. (eds.) Proceedings of the $16^{\text {th }}$ International Silage Conference, 2-4 July, MTT Agrifood Research Finland, University of Helsinki, Hämeenlinna, Finland. p. 378-379.

Kung, L., Stokes, M. \& Lin, C. 2003. Silage additives. In: Buxton, D.R., Muck, R.R. \& Harrison, J.H. (eds). Silage science and technology Agronomy 42. Madison, Wisconsin, USA. p. 305-360.

Laitila, A., Alakomi, H.L., Raaska, L., Mattila-Sandholm, T. \& Haikara, A. 2002. Antifungal activities of two Lactobacillus plantarum strains against Fusarium moulds in vitro and in malting barley. Journal of Applied Microbiology 93: 566-576.

Leuschner, R., Jan, B. \& Paul, S. 2003. Enumeration of probiotic pediococci in animal Feed. Interlaboratory Study 86: 791-801. 
McAllister, T., Selinger, L., McMahon, L., Bae, H., Lysyk, T., Oosting, S. \& Cheng, K. 1995. Intake, digestibility and aerobic stability of barley silage inoculated with mixtures of Lactobacillus plantarum and Enterococcus faecium. Canadian Journal of Animal Science 75: 425-432.

McDonald, P., Henderson, A. \& Heron, S. 1991. Biochemistry of Silage, 2nd ed. Marlow, UK: Chalcombe Publications. 340 p.

Moran, J., Weinberg, Z.G. \& Ashbell, G. 1996. A comparison of two methods for the evaluation of the aerobic stability of whole crop wheat silage. In: Jones, D. et al.(eds.) Proceedings of the 11th International Silage Conference, 8-11 September, University of Wales, Aberystwyth, UK. p. 162-163.

Muck, R. 2012. Microbiology of ensiling: In: Kuoppala, K. et al. (eds.) Proceedings of the 16th International Silage Conference, 2-4 July, MTT Agrifood Research Finland, University of Helsinki, Hameenlinna, Finland. p. 75-86.

Nadeau, E., Buxton, D., Russell, J., Allison, M. \& Young, J. 2000. Enzyme, bacterial inoculant, and formic acid effects on silage composition of orchardgrass and alfalfa. Journal of Dairy Science 83: 1487-1502.

Oude Elferink, S., Krooneman, J. \& Gottschal, J. 2001. Anaerobic conversion of lactic acid to acetic acid and 1,2-propanediol by Lactobacillus buchneri. Applied and Environmental Microbiology 67: 125-132.

Pahlow, G., Muck, R., Driehuis, F., Oude Elferink, S. \& Spoelstra, S. 2003. Microbiology of ensiling. In: Buxton, D.R., Muck, R.R. \& Harrison, J.H. (eds). Silage science and technology Agronomy 42. Madison, Wisconsin, USA. p. 31-93.

Playne, M.K. \& McDonald, P. 1966. The buffering constituents of herbage and of silage. Journal of the Science of Food and Agriculture 17: 264-268.

Ranjit, K. \& Kung, L.Jr. 2000. The Effect of Lactobacillus buchneri, Lactobacillus plantarum, or a Chemical Preservative on the Fermentation and Aerobic Stability of Corn Silage. Journal of Dairy Science 83: 526-535.

Rooke, J. \& Hatfield, R. 2003. Biochemistry of ensiling. In: Buxton, D.R., Muck, R.R. \& Harrison, J.H. (eds). Silage science and technology Agronomy 42. Madison, Wisconsin, USA. p. 95-139.

Schmidt, R., Hu, W., Mills, J. \& Kung, L. 2009. The development of lactic acid bacteria and Lactobacillus buchnery and their effects on the fermentation of alfalfa silage. Journal of Dairy Science 92: 5005-5010.

Saarisalo, E., Jaakola, S., Skyttä, E. \& Jalava, T. 2006a. Screening and selection of lactic acid bacteria strains suitable for ensiling grass. Journal of Applied Microbiology 102: 327-336.

Saarisalo, E., Jalava, T., Skyttä, E \& Haikara, A. 2006b. Effect of lactic acid bacteria inoculants, formic acid, potassium sorbate and sodium benzoate on fermentation quality and aerobic stability of wilted grass silage. Agricultural and Food Science 15: 185-199.

Statistical Analysis System SAS . 2002. User's Guide: Statistics, Version 8.02. SAS Institute Inc. - Cary, USA.

Van Soest, P., Robertson, J. \& Lewis, B. 1991. Methods for dietary fiber, neutral detergent fiber, and nonstarch polysaccharides in relation to animal nutrition. Journal of Dairy Science 74: 3583-3597.

Weinberg, Z., Ashbell, G. \& Hen, Y. 1999. The effect of Lactobacillus buchneri and L. plantarum, applied at ensiling, on the ensiling fermentation and aerobic stability of wheat and sorghum silages. Journal of Industrial Microbiology and Biotechnology 23: 218-222.

Weissbach, F. 2009. Correction of dry matter content of silages used as substrate for biogas production. In: Broderick, G.A. (eds.). Proceedings of the 15th International Silage Conference, in July in Madison, Wisconsin, USA. University of Wisconsin-Madison: College of Agricultural and Life Science. p. 483-484.

Winters, A., Cockburn, J., Dhanoa, M. \& Merry, R.J. 2000. Effects of lactic acid bacteria in inoculants on changes in amino acid composition during ensilage of sterile and non-sterile ryegrass. Journal of Applied Microbiology 89: 442-451.

Woolford, M. 1975. Microbiological screening of food preservatives: cold sterilants and specific antimicrobial agents as potential silage additives. Journal of the Science of Food and Agriculture 26: 229-237.

Wyss, U. \& Rubenshuh, U. 2012. Efficacy of three different silage inoculants on the fermentation quality and aerobic stability of ryegrass ensiled with three different prewilting degrees. In: Kuoppala, K. et al. (eds.) Proceedings of the 16th International Silage Conference, 2-4 July, MTT Agrifood Research Finland, University of Helsinki, Hämeenlinna, Finland. p. 386-387. 